\title{
Effectiveness of Guided Discovery Model Learning Materials for Practicing Student Science Process Skills
}

\author{
Candra Indi Kumala, Suyatno, Elok Sudibyo
}

\author{
Science Education Program \\ Post-Graduate Of Universitas Negeri Surabaya \\ Surabaya, Indonesia \\ candra.17070795032@mhs.unesa.ac.id \\ DOI: 10.29322/IJSRP.10.02.2020.p9821 \\ http://dx.doi.org/10.29322/IJSRP.10.02.2020.p9821
}

\begin{abstract}
This study aims to describe the effectiveness of learning tools with guided discovery models to train students' science process skills at SMAN 1 Kedungwaru, Tulungagung on the subject matter of simple harmonic vibrations. The learning tool was developed using the 4D model and the trial design used was One Group Pretest and Posttest Design. Data collection was carried out using validation techniques, science process skills tests and questionnaires. The results of the learning device validation showed the following averages: Syllabus (3.88), RPP Scenario (3.88), Student Book (3.83), Student Worksheet (3.77), and science process skills tests (3.87) which quite valid. The science process skills test showed the classical completeness of the students of class XI MIPA 4 was $92.86 \%$; class XI MIPA 5 by $92.59 \%$; and class XI MIPA 6 by $93.10 \%$. The score for the XI MIPA 4, XI MIPA 5 and XI MIPA 6 classes is $0.82 ; 0.82$; and 0.83 which is included in the high category. Students gave positive responses to the learning tools developed for all three classes by $91 \%, 89 \%$, and $91 \%$. Based on the results of the study it can be concluded that the guided discovery model of learning devices is declared effective in training students' science process skills.
\end{abstract}

Keywords: Learning tools, guided discovery, science process skills, simple harmonic vibrations

\section{Introduction}

Natural Sciences deals with how to find out about nature systematically, so that science is not only mastering a collection of knowledge in the form of facts, concepts, or principles, but also a process of discovery (Permendikbud, 2014). Science is basically divided into three components, namely scientific attitude, scientific process, and scientific products. Based on these three components, it can be seen that science is not just a collection of knowledge but also an active process of using the mind to study natural phenomena that have not been imagined. According to the Ministry of National Education (2008) concluded that learning science in schools makes reference to learning outcomes are assessed on the results of tests or examinations only and are not oriented to the achievement of Basic Competencies so that the lack of learning experience gained by students during class. Science is only delivered in the form of products and student activities only memorize factual information, students also only study science in the low cognitive domain so that it makes students not accustomed to developing their thinking potential.

Graduates Competency Standards and Content Standards are very closely related to the characteristics of learning in each education unit. Permendibud No. 22 on Basic and Secondary Education Process Standards states that the principles of scientific and scientific approaches are needed in the process of learning. Science and technology is currently increasingly advanced and can not be separated from the findings in the field of science. The development of ongoing technology requires teachers to increasingly think creatively and can make a variety of new innovations in learning because teachers not only convey information but teachers must also be able to teach and instill understanding to students in order to solve problems faced so students can develop and be competent and can answer future challenges. Development of problem solving skills in students is not easy, so special skills are needed called science process skills.

Science process skills are the basis of problem solving in science and scientific methods and are therefore very important to learn (Wilujeng et al., 2010). According to Permendibud No. 58 of 2014 the aim of science learning is to foster the ability to think, work, communicate, and be scientific. Science learning emphasizes the provision of direct learning experiences through the development and use of scientific process skills and attitudes. Science learning in its implementation should be carried out in inquiry (scientific inquiry) so that it can train and develop several aspects, namely aspects of knowledge, science process skills, and critical thinking (Kemendikbud, 2014).

According to Ibrahim (2010) science process skills are skills to do the science process that is the skills to develop, 
find knowledge, and apply science. Process skills can encourage students to independently discover facts, concepts of knowledge and develop attitudes and values that are demanded (Wulanningsih et al., 2012). Mastery of science process skills becomes something absolute for someone who is studying science (Subiyantoro, 2012). Learning will be more meaningful if the student participates in the learning process. Where in it is provided a problem the students begin by observing then they will arise the question why this can occur so that they will make an inquiry effort to resolve the problem. The process will make students more familiar with what problems they are solving. Therefore science process skills are very important to learn and do in the learning process.

Based on observations and interviews of students and teachers at SMAN 1 Kedungwaru, it appears that not all Physics learning is accompanied by practical activities. In physics learning only given ILAU (Independent Learning Activity Unit) to be done individually. The learning model used also still uses the conventional learning model in which it has not facilitated students to do practical work. Understanding of the material will be more pervasive if students do their own practicum because students take an active role in the process of finding answers to problems encountered. Especially in Simple Harmonious Vibration material, students are not trained to do practical work because they have not implemented an innovative learning model that can facilitate students to learn accompanied by practical activities. In this school there is also no student worksheet in the form of practical activities so students only work on ILAU provided by the teacher. The learning model used is also still teacher-centered so students are less trained in doing practical activities. This makes students get less learning experience from the material being taught.

The results of the pre-research that have been done show that the science process skills at SMAN 1 Kedungwaru are also still relatively low in several aspects. Only a few students answered questions about correct science process skills, for aspects of formulating problems (14\%), aspects of formulating hypotheses (28\%), aspects of identifying variables (7\%), aspects of planning an experiment (17\%), aspects of making tables ( $35 \%)$, graph (3\%), and make conclusions (39\%). That is because students are not taught to do practicum in several chapters, especially on simple harmonic vibration material. Students' interest is also lacking in Physics because they accept material that is mostly in the form of formulas, principles, and laws so that students feel bored to know more about the material provided. Based on these observations it can be concluded that the science process skills of students are less trained because they are not accustomed to doing practical activities. Therefore we need learning activities that can facilitate students to improve students science process skills.

The learning model that allows being able to actively involve students in learning one of them is the guided discovery model. Guided discovery is a learning model that integrates teacher and student-centered teaching methods.
According to Carin (1993) the guided discovery model is a learning model that guides and helps students learn to gain knowledge, and discover unique concepts by the way they find themselves. Students must be encouraged to study independently. Guided discovery can be implemented in learning because it can motivate students to learn to find concepts they learn independently through their own learning experiences. This agrees with the results of research Ilmi et al. (2012) learning activities using guided discovery learning models are proven to train students in developing science process skills so that the nature of science as a process and product in learning can be maximally implemented. The guided discovery model can improve students' science process skills (Azizirrahim et al., 2015). Related to the above findings, this study aims to determine the effectiveness of the guided discovery learning model to train students' science process skills.

\section{Method}

This study uses guided discovery model learning tools to practice science process skills to train students' science process skills. Learning tools used consist of: syllabus, RPP Scenario, Student Book, Student Worksheets, and science process skills tests developed with the 4D model and tested for eligibility before being applied in learning. The learning kit was tested in class XI MIPA 4, class XI MIPA 5, and class XI MIPA 6 at SMAN 1 Kedungwaru, Tulungagung by involving 84 students using the One Group Pretest-Posttest Design model. Data collection methods used were validation, tests, and questionnaires. The research data are processed descriptively.

\section{Result and Discussion}

Learning Device Validation

The results of the validity score of the guided discovery learning model can be seen in the following explanation:

Table 1. Validity scores of learning devices

\begin{tabular}{llcl}
\hline No. & Name & $\begin{array}{c}\text { Validity } \\
\text { Score }\end{array}$ & Category \\
\hline 1. & Syllabus & 3,88 & Very Valid \\
\hline 2. & Learning Scenario & 3,88 & Very Valid \\
\hline 3. & Student's Book & 3,83 & Very Valid \\
\hline 4. & Student's & 3,77 & Very Valid \\
& Worksheet & & \\
\hline 5. & $\begin{array}{l}\text { Science Process } \\
\text { Skills Tests }\end{array}$ & 3,87 & Very Valid \\
\hline
\end{tabular}

Based on the data obtained, it shows that all guided discovery learning models have a very valid category. It can be concluded that the guided discovery learning model can be used to train students' science process skills.

\section{Science Process Skill Test}

Science process skills tests are used to determine the effectiveness of the learning tools developed. The test is done before or called the pretest and the test after learning is

www.ijsrp.org 
posttest. Pretest is done before learning which aims to determine the students 'initial ability in aspects of science process skills while the posttest is done at the end of learning using guided discovery learning models to train science process skills that aim to find out the extent of students' final knowledge after teaching and learning activities are carried out. The results of the pretest and posttest scores are then used to calculate the n-gain score. The $\mathrm{N}$-gain score is used to determine the types of science process skill categories between before and after learning by using the guided discovery model. Science activities require science process skills by applying discovery models (Aydinli, E. et al., 2011).

The application of guided discovery models can improve students' science process skills (Astra \& Wahidah, 2017). These results are proven to strengthen the results of research conducted by researchers. Where the results of the value of science process skills have increased with the application of guided discovery models. The value of science process skills in grade XI MIPA 4 students in the pretest activities of students obtained an average of 37.08 with incomplete criteria (TT). After learning activities using the guided discovery model the results of the students' posttest score increased by an average of 88.44 with the completion criteria (T) and the n-gain of the class average of 0.82 with high criteria but there were still 2 students who were still incomplete. The value of science process skills in grade XI MIPA 5 students in the pretest activities of students obtained an average of 39.15 with incomplete criteria (TT). After learning activities using the guided discovery model the results of the students' posttest scores increased by an average of 88.89 with complete criteria $(\mathrm{T})$ and $\mathrm{n}$-gain grade average of 0.82 with high criteria but there were still 2 students who were still incomplete. The value of science process skills in grade XI MIPA 6 students in the pretest activities of students obtained an average of 38.75 with incomplete criteria (TT). After learning activities using guided discovery models the results of students' posttest scores increased by an average of 89.82 with complete criteria $(\mathrm{T})$ and $\mathrm{n}$-gain grade average of 0.82 with high criteria but there were still 2 students who were still incomplete. Students who are declared incomplete are given possible solutions in the form of remidial learning to achieve the completeness of learning objectives. In this learning guided discovery model or can be called a discovery model can improve science process skills. These results have also been proven by Bekiroglu, F. O., \& Arslan, A. (2014) proving that classes using discovery learning models improve students' science process skills. Science process skills can influence the teaching of physics and are one important component that must be learned before studying content (Hodosyova, et al., 2015). Research by Handayani et al. (2018) states that guided discovery learning is effective for improving students' science process skills. Judging from the research results of researchers and from the results of several other researchers it can be concluded that the guided discovery model can improve students' science process skills.
The results of the achievement of students' science process skills in the three classes are as follows:

Table 2

Achievement of Science Process Skills for Each Class Indicator XI MIPA 4

\begin{tabular}{lcc}
\hline Aspect & $\begin{array}{c}\text { Achievement } \\
\text { Pretest (\%) }\end{array}$ & $\begin{array}{c}\text { Achievement } \\
\text { Posttest (\%) }\end{array}$ \\
\hline $\begin{array}{l}\text { Determine the } \\
\text { formulation of the } \\
\text { problem }\end{array}$ & 36,90 & 91,67 \\
\hline $\begin{array}{l}\text { Formulate a } \\
\text { hypothesis }\end{array}$ & 32,14 & 91,67 \\
\hline $\begin{array}{l}\text { Identifying } \\
\text { variables }\end{array}$ & 21,43 & 83,33 \\
\hline $\begin{array}{l}\text { Design an } \\
\text { experiment }\end{array}$ & 42,86 & 95,24 \\
\hline Make a table & 44,05 & 90,48 \\
\hline Make a graph & 35,71 & 80,95 \\
\hline Make conclusions & 46,43 & 85,71 \\
\hline
\end{tabular}

Table 3

Achievement of Science Process Skills for Each Class Indicator XI MIPA 5

\begin{tabular}{lcc}
\hline Aspect & $\begin{array}{r}\text { Achievement } \\
\text { Pretest (\%) }\end{array}$ & $\begin{array}{r}\text { Achievement } \\
\text { Posttest (\%) }\end{array}$ \\
\hline $\begin{array}{l}\text { Determine the } \\
\text { formulation of the } \\
\text { problem }\end{array}$ & 40,74 & 91,36 \\
\hline $\begin{array}{l}\text { Formulate a } \\
\text { hypothesis }\end{array}$ & 22,22 & 96,30 \\
\hline $\begin{array}{l}\text { Identifying } \\
\text { variables }\end{array}$ & 27,16 & 86,42 \\
\hline $\begin{array}{l}\text { Design an } \\
\text { experiment }\end{array}$ & 43,21 & 85,19 \\
\hline Make a table & 49,38 & 83,95 \\
\hline Make a graph & 38,27 & 90,12 \\
\hline Make conclusions & 55,56 & 90,12 \\
\hline
\end{tabular}

Table 4

Achievement of Science Process Skills for Each Class Indicator XI MIPA 6

\begin{tabular}{lcc}
\hline Aspect & $\begin{array}{c}\text { Achievement } \\
\text { Pretest (\%) }\end{array}$ & $\begin{array}{c}\text { Achievement } \\
\text { Posttest (\%) }\end{array}$ \\
\hline $\begin{array}{l}\text { Determine the } \\
\text { formulation of the } \\
\text { problem }\end{array}$ & 34,48 & 88,51 \\
\hline $\begin{array}{l}\text { Formulate a } \\
\text { hypothesis }\end{array}$ & 34,48 & 93,10 \\
\hline $\begin{array}{l}\text { Identifying } \\
\text { variables }\end{array}$ & 22,99 & 80,46 \\
\hline $\begin{array}{l}\text { Design } \\
\text { experiment }\end{array}$ & 37,93 & 95,40 \\
\hline Make a table & 47,13 & 88,51 \\
\hline Make a graph & 48,28 & 93,10 \\
\hline Make conclusions & 47,13 & 90,80 \\
\hline
\end{tabular}

Student Response

Student response data related to learning with the application of guided discovery models to train students' scientific processes. Student responses to the learning tools 
developed are seen from students' interest in student textbooks, student worksheets, learning materials, how teachers teach, the learning atmosphere, and the questions of science process skills. The results obtained from class XI MIPA 4, XI MIPA 5 and XI MIPA 6, the average student filled out by expressed interest with a percentage of $91 \%, 89 \%$, and $91 \%$. The results stated that most students were interested in the learning tools used by the teacher. From this interest the teacher is easier to take the attention of students so they are eager to carry out learning activities. Science process skills with guided discovery learning models get a dominant percentage with positive categories (Suratmi, et al., 2016).

From this research, it can be seen the effectiveness of the use of guided discovery learning tools to train science process skills very well. Researchers conduct research by examining in depth about library studies to determine the opportunities for effective use of guided discovery learning models to practice science process skills.

\section{Conclusion}

Based on the research results obtained, the conclusion is that the guided discovery model of learning tools is effective for training students' science process skills.

\section{References}

Astra, I. M., \& Wahidah, R. S. (2017). Peningkatan Ketarmpilan Proses Sains Peserta Didik Melalui Model Guided Discovery Learning Kelas XI MIPA pada Materi Suhu dan Kalor. Jurnal Penelitian \& Pengembangan Pendidikan Fisika. Vol. 3 No. 2, pp 181-190

Aydinli, E., Dokme, I., Unlu, Z. K., Ozturk, N., Demir, R., \& Benli, E. (2011). Turkish Elementary School Students' Performance on Integrated Science Process Skill. Procedia - Social and Behavioral Sciences, pp 3469-3475

Azizirrahim, E., Sutrio, Gunawan. (2015). Penerapan Pendekatan Keterampilan Proses Sains dalam Model Pembelajaran Guided Discovery untuk Meningkatkan Hasil Belajar IPA Fisika pada Siswa Kelas VII A SMPN 8 Mataram Tahun Ajaran 2015/2016. Jurnal Pendidikan Fisika dan Terknologi (ISSN. 2407-6902) Vol. 1 No. 4, pp 272-275

Bekiroglu, F. O., \& Arslan, A. (2014). Examination of the Effects of Model-Based Inquiry on Students' Outcomes: Scientific Process Skills and Conceptual Knowledge. Science Direct. Procedia - Social and Behavioral Sciences 141, pp 1187-1191

Carin, A. A. (1993). Teaching Science Through Discovery. United State of America: Macmillan Publishing Company

Depdiknas. (2008). Panduan Pengembangan Bahan Ajar. Jakarta: Departemen Pendidikan Nasional Direktoral
Jenderal Manajemen Pendidikan Dasar dan Menengah Direktorat Pembinaan Sekolah Menengah Atas

Handayani, A. S., Kirana, T., Rahayu, Y. S., \& Jayanti, P. (2018). Implementation of Guided Discovery Learning to Improve Student Science Process Skill of Junior High School. Atlantis Press. 2nd International Conference on Education Innovation (ICEI 2018)

Hodosyova, M., Utla, J., Vanyova, M., Vnukova, P., \& Lapitkova, V. (2015). The Development of Science Process Skills in Physics Education. Science Direct. Procedia Social and Behavioral Sciences 186, pp 982-989

Ibrahim, M. (2010). Dasar-dasar Proses Belajar Mengajar. Surabaya: Unesa University Press

Ilmi, Abrari N. A., Indrowati, M., \& Probosari, R. M. (2012). Pengaruh Penerapan Metode Pembelajaran Guided Discovery Terhadap Keterampilan Porses Sains Siswa Kelas X SMA Negeri 1 Teras Boyolali Tahun Pelajaran 2011/2012. Jurnal Pendidikan Biologi Volume 4 Nomor 2, pp 44-52

Permendikbud. (2014). Peraturan Menteri Pendidikan dan Kebudayaan Republik Indonesia Nomor 103 Tahun 2014 tentang Pembelajaran pada Pendidikan Dasar dan Menengah. Jakarta: Menteri Pendidikan dan Kebudayaan RI

Permendikbud. (2014). Peraturan Menteri Pendidikan dan Kebudayaan Republik Indonesia Nomor 58 Tahun 2014 tentang Kurikulum 2013 SMP/MTs. Jakarta: Menteri Pendidikan dan Kebudayaan RI

Permendikbud. (2016). Peraturan Menteri Pendidikan dan Kebudayaan Republik Indonesia Nomor 22 Tahun 2016 tentang Standar Proses Pendidikan Dasar dan Menengah. Jakarta: Menteri Pendidikan dan Kebudayaan RI

Subiantoro, A. W. (2012). Pentingnya Praktikum dalam Pembelajaran IPA. Makalah yang disampaikan pada Kegiatan PPM "Pelatihan Pengembangan Praktiku IPA Berbasis Lingkungan” bagi guru-guru MGMP IPA SMP Kota Yogyakarta

Suratmi, Khastini, R. O, \& Fauziah, N. L. (2016). Learning Process of Biology Through the Guided Discovery Learning Based on Local Excellence on the Subconcept of Eubacteria Role in Lifa. Proceedings of the $2^{\text {nd }} S U L E-I C$, FKIP, UNSRI. October $7^{\text {th }}-9^{\text {th }}, 2016$, pp 1141-1154

Wilujeng, I., Setiawan, A., \& Liliasari. 2010. Kompetensi IPA Terintegrasi Melalui Pendekatan Keterampilan Proses Mahasiswa S-1 Pendidikan IPA. Jurnal Cakrawala Pendidikan, Th. XXIX, No. 3, pp 353-364

Wulanningsih, S., Prayitno, B. A., \& Probosar, R. M. (2012). Pengaruh Model Pembelajaran Inkuiri Terbimbing Terhadap Keterampilan Proses Sains Ditinjau dari Kemampuan Akademik Siswa SMA Negeri 1 Surakarta. Pendidikan Biologi Vol.4, No. 2, 4 (2), pp 33-43 